\title{
DYNAMIC MAGNETIC RESONANCE IMAGING: PRELIMINARY PRESENTATION OF A TECHNIQUE
}

\author{
RESSONÂNCIA MAGNÉTICA DINÂMICA: APRESENTAÇÃO PRELIMINAR DE UMA TÉCNICA
}

RESONANCIA MAGNÉTICA DINÁMICA: PRESENTACIÓN PRELIMINAR DE UNA TÉCNICA

Bruno da Costa Ancheschi ${ }^{1}$, Aniello Savarese ${ }^{1}$, Raphael de Rezende Pratali², Daniel Augusto Carvalho Maranho ${ }^{1}$, Marcello Teixeira Castilha ${ }^{1}$,

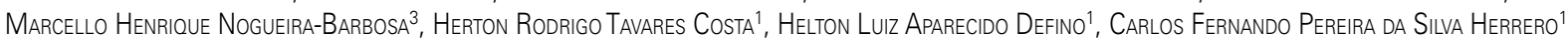

1. Universidade de São Paulo, Faculdade de Medicina de Ribeirão Preto, Hospital das Clínicas, Department of Locomotor Apparatus Biomechanics, Medicine, and Rehabilitation,
Ribeirão Preto, SP, Brazil.
2. Hospital do Servidor Público Estadual (HSPE), São Paulo, SP, Brazil.
3. Universidade de São Paulo, Faculdade de Medicina de Ribeirão Preto, Hospital das Clínicas, Radiology Division of the Department of Clinical Medicine, Ribeirão Preto, SP, Brazil.

\begin{abstract}
Objective: To evaluate morphometric variations of the cervical spine in patients with cervical spondylotic myelopathy (CSM) using dynamic magnetic resonance imaging (MRI) in neutral, flexion and extension positions. Methods: This is a prospective study of patients with CSM secondary to degenerative disease of the cervical spine. The morphometric parameters were evaluated using T2-weighted MRI sequences in the sagittal plane in neutral, flexion and extension position of the neck. The parameters studied were the anterior length of the spinal cord (ALSC), the posterior length of the spinal cord (PLSC), the diameter of the vertebral canal (DVC) and the diameter of the spinal cord (DSC). Results: The ALSC and PLSC were longer in flexion than in extension and neutral position, with statistically significant difference between the flexion and extension position. The DVC and the DSC were greater in flexion than in extension and neutral position, however, there was no statistically significant difference when they were compared in the neutral, flexion and extension positions. Conclusion: Dynamic MRI allows to evaluate morphometric variations in the cervical spinal canal in patients with cervical spondylotic myelopathy.
\end{abstract}

Keywords: Spondylosis; Cervical vertebrae; Magnetic resonance imaging; Spinal canal.

\section{RESUMO}

Objetivo: Avaliar variações morfométricas da coluna vertebral cervical em pacientes portadores de mielopatia cervical espondilótica (MCE) por meio da ressonância magnética dinâmica nas posições neutra, em flexão e em extensão. Métodos: Este é um estudo prospectivo de pacientes portadores de MCE secundária à doença degenerativa da coluna vertebral cervical. Os parâmetros morfométricos foram avaliados pelas sequências de ressonância magnética ponderadas em T2, no plano sagital em posições neutra, flexão e extensão. Os parâmetros estudados foram o comprimento anterior da medula espinhal (CAME), o comprimento posterior da medula espinhal (CPME), o diâmetro do canal vertebral (DCV) e o diâmetro da medula espinhal (DME). Resultados: O CAME e o CPME foram mais longos em flexão do que nas posições neutra e em extensão, sendo encontrada diferença estatisticamente significativa entre a posição em flexão e extensão. O DCV e o DME foram maiores em flexão do que nas posições neutra e em extensão, no entanto não foi encontrada diferença estatisticamente significativa quando comparados nas posições neutra, em flexão e em extensão. Conclusão: O exame de ressonância magnética dinâmica permite avaliar as variações morfométricas do canal vertebral cervical em pacientes portadores de mielopatia cervical espondilótica.

Descritores: Espondilose; Vértebras cenicais; Imagem por ressonância magnética; Canal vertebral.

\section{RESUMEN}

Objetivo: Evaluar las variaciones morfométricas de la columna cervical en pacientes con mielopatía cenvical espondilótica (MCE) mediante resonancia magnética dinámica en la posición neutra, en flexión y extensión. Métodos: Se trata de un estudio prospectivo de pacientes con MCE secundaria a la enfermedad degenerativa de la columna cervical. Los parámetros morfométricos fueron evaluados en las secuencias ponderadas en T2 en el plano sagital en la posición neutra, en flexión y extensión de la resonancia magnética. Los parámetros estudiados fueron la longitud anterior de la médula espinal (LAME), la longitud posterior de la médula espinal (LPME), el diámetro del canal espinal (DCE) y el diámetro de la médula espinal (DME). Resultados: La LAME y la LPME fueron más largas en flexión que en las posiciones neutra y en extensión, con diferencia estadísticamente significativa entre la posición en flexión y extensión. El DME y el DCE fueron mayores en flexión que en extensión y la posición neutra, sin embargo no hubo diferencia estadísticamente significativa cuando se compararon en la posición neutral, en flexión y extensión. Conclusión: El examen de resonancia magnética dinámica permite evaluar los cambios morfométricos en el canal espinal cervical en pacientes con mielopatía cervical espondilótica.

Descriptores: Espondilosis; Vértebras cenicales; Imagen por resonancia magnética; Conducto vertebral.

\section{INTRODUCTION}

Cervical spondylotic myelopathy (CSM) is directly related to narrowing of the cervical spinal canal. ${ }^{1-4}$ Reduction in the diameter of the vertebral canal secondary to intervertebral disc degeneration and the production of osteophytes leads to static and dynamic compression of the spinal cord and the nerve roots, and can produce direct lesions and secondary ischemic changes. ${ }^{5-7}$

Magnetic resonance (MRI) is the imaging exam of choice for the 
evaluation of CSM because, in addition to identifying intramedullary lesions, it is capable of showing compression of the cervical spinal canal. ${ }^{8}$ The dynamic MRI modality has been studied by several authors, involving healthy individuals. ${ }^{5}$ However, there is little available information in the literature about the evaluation of patients with CSM using dynamic magnetic resonance. ${ }^{5}$ Consequently, the morphological, physiological, and pathological variations in the different positions of the cervical spine revealed by dynamic magnetic resonance imaging (DMRI) were described. ${ }^{5}$

This study was conducted in response to our observation of the lack of methodological standards for performing DMRI. The hypothesis of our study was the existence of variations between the morphometric measurements of the cervical spine taken from the routinely performed MRI and those from DMRI. The objective was to evaluate the morphometric variations of the cervical spine in patients with CSM in the neutral, flexion, and extension cervical positions using dynamic magnetic resonance imaging.

\section{MATERIALS AND METHODS}

Following the approval of the Institutional Review Board, we conducted a retrospective study of 15 patients diagnosed with cervical spondylotic myelopathy secondary to degenerative cervical spine disease, during the period from January 2015 to December 2015. All patients met the criteria for CSM. ${ }^{9-14}$ Twelve (80\%) of the patients were male and three (20\%) were female, with an average age of 58.4 years ( 37 to 70 years). The inclusion criteria were a clinical and radiographic diagnosis of CSM secondary to degenerative cervical spine disease, an age greater than 18 years, and a signed informed consent form. Patients younger than 18 years of age, those with a history of previous cervical spine surgery, without a clinical and radiographic diagnosis of CSM secondary to degenerative cervical spine disease, and those refusing to participate or to sign the informed consent form were excluded.

All patients underwent an MRI exam of the cervical spine using the same apparatus (Magnetic Resonance 1.5T, Achieva, Philips) supervised by one of the study authors (BCA) and members of the hospital medical staff. The patients were conscious and responsive to constant questioning during the exam in order to avoid the occurrence of neurological complications. During the first step, the exam was conducted with the patients in the routine supine position with the neck in the neutral position (Figure 1A) to obtain the conventional T1 and T2-weighted sagittal and T2-weighted axial sequences. In the second step, the patient was asked to perform maximum flexion of the neck, according to tolerance, a pad was positioned under the patient's head (Figure 1B), and a T2-weighted sequence in the sagittal plane was obtained. In the third step, the patient was asked to perform the maximum tolerable extension of the neck, a pad was placed under the patient's shoulders to maintain the extension (Figure 1C), and a T2-weighted sequence in the sagittal plane was once again obtained.

The morphometric parameters were evaluated in the T2-weighted $\mathrm{MRI}$ sequences of the neutral, flexion, and extension positions. The parameters studied were the anterior length of the spinal cord (ALSC), the posterior length of the spinal cord (PLSC), the diameter of the vertebral canal (DVC), and the diameter of the spinal cord (DSC). (Table 1) All the images were analyzed by the same observer (BCA) using the OsiriX MD v.7.0 64-bit program under standardized 300\% magnification.

The limits used for the calculation of the ALSC and PLSC between $\mathrm{C} 1$ and $\mathrm{C} 7$ were a straight line crossing the spinal cord the upper edge of the anterior and posterior arcs of $\mathrm{C} 1$ and a straight line passing along the lower terminal plate of C7. (Figure 2) The DVC was measured as the shortest distance between the center of the posterior edge of the intervertebral disc of each segment (for example, C2-C3, C3-C4, etc.) and the anterior edge of the ligamentum flavum posteriorly. (Figure 3A) The DSC was measured in the same cuts used to calculate the DVC as the shortest distance between the anterior and posterior edges of the spinal cord. (Figure 3B)
A descriptive data analysis was performed using the STATA 14.1 statistical analysis program. The data were expressed as averages and standard deviations, with a significance level of $5 \%$.

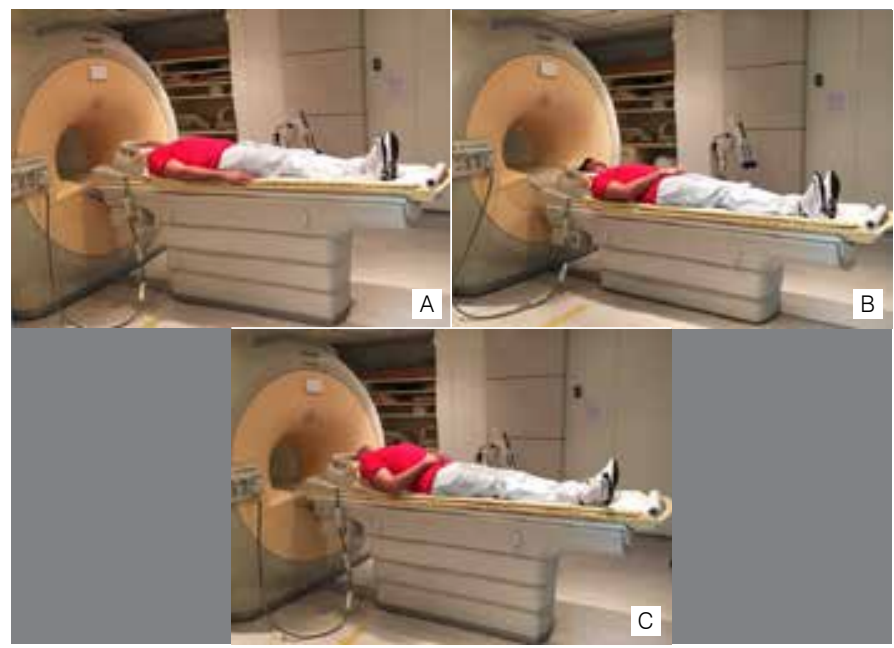

Figure 1. Pictures of the author A.S. showing the methodology used during the dynamic magnetic resonance exam in neutral $(A)$, flexion $(B)$, and extension (C) positions.

Table 1. Morphometric parameters evaluated by means of DMRI.

\begin{tabular}{c|c}
\hline ALSC & Anterior length of the spinal cord \\
\hline PLSC & Posterior length of the spinal cord \\
\hline DVC & Diameter of the vertebral canal \\
\hline DSC & Diameter of the spinal cord \\
\hline
\end{tabular}

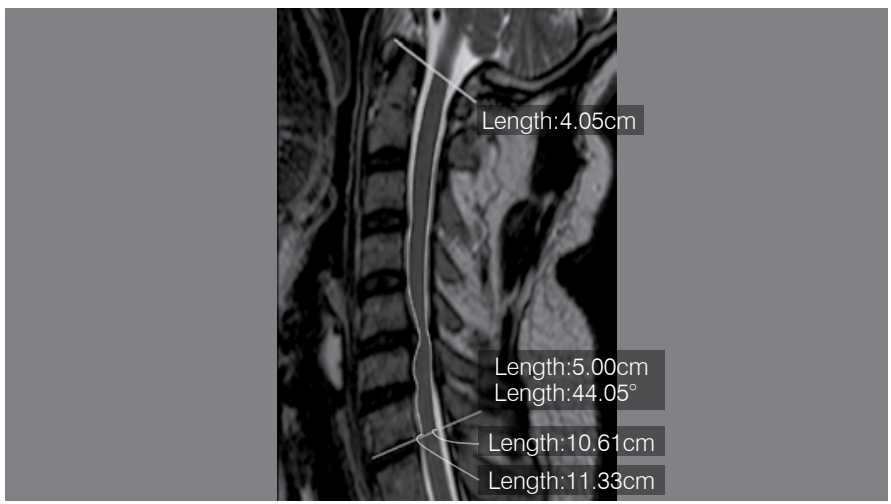

Figure 2. T2-weighted sagittal MRI cuts showing the ALSC and PLSC measurements.

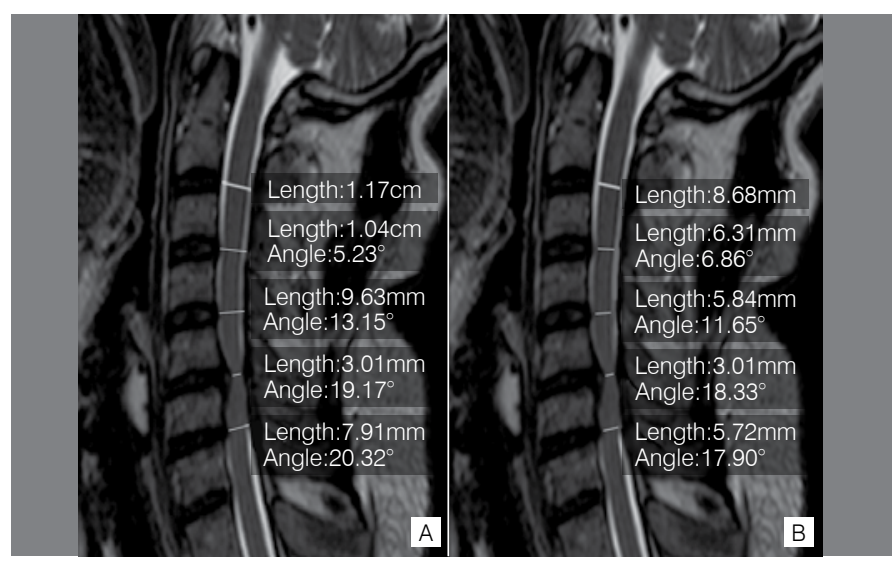

Figure 3. T2-weighted sagittal MRI cuts showing the DVC (A) and DSC (B) measurements. 


\section{RESULTS}

Although DMRI has been used before to study patients with CSM, there is a lack of evidence showing morphological variations in the cervical spine resulting from flexion and extension of the neck. To demonstrate these changes by morphometric evaluation of DRMI is no easy task. Our study is based on a morphometric evaluation of the lengths of the spinal cord and the diameters of the spinal cord and the spinal canal in neutral, flexion, and extension positions. All patients were able to undergo the dynamic exam, with varying levels of discomfort. None of the exams needed to be discontinued due to the occurrence of neurological changes during the exam.

The average ALSC obtained from the exam was longer in flexion than in the neutral and extension positions. (Table 2) No statistically significant difference was found when we compared the ALSCs in the neutral and flexion positions or in the neutral and extension positions. However, we did find a statistically significant difference between the flexion and extension positions ( $p=0.002)$.

Like the ALSC, the average PLSC was longer in flexion than in the neutral and extension positions. (Table 2) We found no statistically significant difference when we compared the ALSC in the neutral and flexion positions or in the neutral and extension positions. However, we did find a statistically significant difference between the flexion and extension positions $(p=0.000)$. The ALSC was longer than the PLSC in all three positions (neutral, flexion, and extension). (Table 2)

When we evaluated the average DVC, the values in flexion were greater than in the neutral and extension positions in all segments studied. (Table 3) However, we did not find any statistically significant difference when we compared the values of the DVC in neutral, flexion, and extension positions ( $p>0.05)$.

An evaluation of the average DSC values for all segments yielded the same pattern as the DVC, i.e., they were greater in flexion than in the neutral and extension positions. (Table 4) However, we did not find any statistically significant difference when we compared the DSCs in the positions studied $(p>0.05)$.

Table 2. Average cervical spine length values (millimeters).

\begin{tabular}{c|c|c|c}
\hline & Neutral & Flexion & Extension \\
\hline ALSC & $10.83 \pm 0.61$ & $11.25 \pm 0.69$ & $10.49 \pm 0.69$ \\
\hline PLSC & $10.32 \pm 0.6$ & $11.03 \pm 0.67$ & $9.84 \pm 0.71$ \\
\hline
\end{tabular}

Table 3. Average DVC values (millimeters).

\begin{tabular}{c|c|c|c}
\hline & Neutral & Flexion & Extension \\
\hline C2-C3 & $10.05 \pm 2.2$ & $10.08 \pm 2.0$ & $9.3 \pm 2.4$ \\
\hline C3-C4 & $7.33 \pm 3.05$ & $8.22 \pm 2.86$ & $6.73 \pm 3.09$ \\
\hline C4-C5 & $7.37 \pm 2.47$ & $8.65 \pm 2.41$ & $7.11 \pm 2.85$ \\
\hline C5-C6 & $7.59 \pm 1.93$ & $8.83 \pm 2.05$ & $7.53 \pm 2.16$ \\
\hline C6-C7 & $8.57 \pm 1.59$ & $9.29 \pm 1.70$ & $8.22 \pm 1.77$ \\
\hline
\end{tabular}

Table 4. Average DSC values (millimeters).

\begin{tabular}{c|c|c|c}
\hline & Neutral & Flexion & Extension \\
\hline C2-C3 & $6.92 \pm 1.32$ & $6.97 \pm 1.29$ & $6.85 \pm 1.21$ \\
\hline C3-C4 & $5.52 \pm 1.48$ & $5.97 \pm 1.36$ & $5.51 \pm 1.67$ \\
\hline C4-C5 & $5.52 \pm 1.48$ & $5.86 \pm 1.16$ & $5.31 \pm 1.49$ \\
\hline C5-C6 & $5.61 \pm 1.13$ & $5.70 \pm 1.11$ & $5.67 \pm 1.25$ \\
\hline C6-C7 & $5.94 \pm 0.88$ & $5.93 \pm 0.95$ & $5.81 \pm 0.85$ \\
\hline
\end{tabular}

\section{DISCUSSION}

Our study findings show that the morphometric characteristics of the cervical spinal canal are related to the position of the neck. In the patients evaluated in this study, the lengths of the spinal cord (ALSC and PLSC) and the diameters of the spinal canal (DVC) and the spinal cord (DSC) were greater in flexion than in the neutral and extension positions. Few studies have investigated the changes to the vertebral canal and spinal cord in patients with cervical spondylotic myelopathy. ${ }^{5}$ As far as we can tell, this is the first time that the diameters of the vertebral canal and the spinal cord have been measured and analyzed at the primary point of compression, i.e., in the space behind the intervertebral disc of each segment of the cervical spine.

According to earlier studies, dynamic factors play an important role in CSM. ${ }^{3,7,8,15,16}$ The great mobility of the cervical spine, more specifically in flexion and extension movements of the neck, can result in changes in the morphometry of the cervical vertebral canal, ${ }^{8,17}$ corroborating to cause and aggravate CSM. ${ }^{9,10}$ Our results show the changes that the dimensions of the vertebral canal and the spinal cord undergo in moving from the neutral position to positions of flexion and extension.

The DRMI exams were conducted with the patients being asked to flex and extend the neck to the maximum tolerable level, always under the supervision of the medical team in order to minimize the risk of neurological changes. These positions were maintained with the support of pads positioned under the patient. Unlike previous studies in which healthy volunteers were used for the DRMI, we opted to limit the flexion and extension of the neck according to the symptomology of each patient, because in the patients evaluated in our study, all of whom suffered from CSM, extreme movements of the cervical spine could cause the onset of a problem or the deterioration of the neurological profile..$^{11-13}$

Just as in the findings of earlier studies, ${ }^{5,15}$ the ALSC and the PLSC were longer in the flexion position than in the neutral and extension positions. Moreover, regardless of the position of the neck, the ALSC was always longer than the PLSC. However, even though we used the previously described methodology, ${ }^{5}$ both the average ALSC and PLSC values recorded in our study were much higher than those previously reported.

The measurements we recorded when evaluating the diameters of the vertebral canal (DVC) and the spinal cord (DSC) were not consistent with those found by Zhang et al. ${ }^{5}$ For both parameters studied, the values measured in the flexion position were greater than those in the neutral and extension positions for all segments evaluated in our study. We did not think wise to compare our results with those previously reported, ${ }^{5}$ given that we could not find details about the methodology used by other authors to investigate these parameters. Thus, we decided to use the site of greatest compression, and consequently of the smallest diameter, in our methodology - the posterior region of the intervertebral disc of each segment of the cervical spine.

Our study has its limitations, such as the small number of patients evaluated and the absence of inter- and intraobserver evaluation. However, the methodology used was very detailed and can be reproduced by future studies to investigate the role of DRMI in evaluating patients with CSM.

\section{CONCLUSION}

The dynamic magnetic resonance imaging exam permits the evaluation of morphometric variations in the cervical spinal canal in patients with cervical spondylotic myelopathy.

All the authors declare that there are no potential conflicts of interest regarding this article.

CONTRIBUTIONS OF THE AUTHORS: Each author made significant individual contributions to the development of both the study and the article. BCA, AS, and HRTC were responsible for the acquisition and compilation of the study data. RRP and CFPSH contributed to the writing of the article. DACM and MTC were responsible for data analysis and statistics. MHNB, HLAD, and CFPSH reviewed the article and supervised the study. All the authors contributed to the intellectual concept of the study. 


\section{REFERENCES}

1. Guidetti $B$, Fortuna A. Long-term results of surgical treatment of myelopathy due to cervical spondylosis. J Neurosurg. 1969:30(6):714-21.

2. Olsson SE. The dynamic factor in spinal cord compression; a study on dogs with special reference to cervical disc protrusions. J Neurosurg. 1958;15(3):308-21.

3. Chen IH, Vasavada A, Panjabi MM. Kinematics of the cervical spine canal: changes with sagittal plane loads. J Spinal Disord. 1994;7(2):93-101.

4. Muhle C, Weinert D, Falliner A, Wiskirchen J, Metzner J, Baumer M, et al. Dynamic changes of the spinal canal in patients with cervical spondylosis at flexion and extension using magnetic resonance imaging. Invest Radiol. 1998;33(8):444-9.

5. Zhang L, Zeitoun D, Rangel A, Lazennec JY, Catonné Y, Pascal-Moussellard H. Preoperative evaluation of the cervical spondylotic myelopathy with flexion-extension magnetic resonance imaging: about a prospective study of fifty patients. Spine (Phila Pa 1976). 2011;36(17):E1134-9

6. Bucher HC, Guyatt GH, Cook DJ, Holbrook A, McAlister FA. Users' guides to the medical literature: XIX. Applying clinical trial results. A. How to use na article measuring the effect of an intervention on surrogate end points. Evidence-Based Medicine Working Group. JAMA. 1999;282(8):771-8.

7. Turnbull IM, Brieg A, Hassler O. Blood supply of cervical spinal cord in man. A microangiographic cadaver study. J Neurosurg. 1966;24(6):951-65.

8. Muhle C, Wiskirchen J, Weinert D, Falliner A, Wesner F, Brinkmann G, et al. Biomechanical aspects of the subarachnoid space and cervical cord in healthy individuals examined with kinematic magnetic resonance imaging. Spine (Phila PA 1976). 1998;23(5):556-67.
9. Fehlings MG, Skaf G. A review of the pathophysiology of cervical spondylotic myelopathy with insights for potential novel mechanisms drawn from traumatic spinal cord injury. Spine (Phila Pa 1976). 1998;23(24):2730-7.

10. Nurick $S$. The pathogenesis of the spinal cord disorder associated with cervical spondylosis. Brain. 1972:95(1):87-100.

11. Denno JJ, Meadows GR. Early diagnosis of cervical spondylotic myelopathy. A useful clinical sign. Spine (Phila Pa 1976). 1991:16(12):1353-5

12. Yugué I, Shiba K, Uezaki N. Static and dynamic modifications of the cervical spine after laminoplasty for cervical spondylotic myelopathy. Rev Chir Orthop Reparatrice Appar Mot. 2003;89(6):487-95

13. Faiss JH, Schroth G, Grodd W, Koenig E, Will B, Thron A. Central spinal cord lesions in stenosis of the cervical canal. Neuroradiology. 1990;32(2):117-23.

14. KuwazawaY, Pope MH, BashirW, Takahashi K, Smith FW. The length of the cervical cord: effects of postural changes in healthy volunteers using positional magnetic resonance imaging. Spine (Phila Pa 1976). 2006;31(17):E579-83.

15. Baron EM, Young WF. Cervical spondylotic myelopathy: a brief review of its pathophysiology, clinical course, and diagnosis. Neurosurgery. 2007;60(1 Supp1 1):S35-41.

16. Young WF. Cervical spondylotic myelopathy: a common cause of spinal Cord dysfunction in older persons. Am Fam Physician. 2000;62(5):1064-70, 1073

17. Holmes A, Han ZH, Dang GT, Chen ZQ, Wang ZG, Fang J. Changes in cervical canal spinal volume during in vitro flexion-extension. Spine (Phila Pa 1976). 1996;21(11):1313-9. 